\title{
MOBILITY OF IMAZETHAPYR DEPENDING ON THE CHARACTERISTICS OF SOIL
}

\author{
Siniša MITRIĆ ${ }^{1 *}$, Vaskrsija JANJIĆ ${ }^{2}$
}

UDK 631.41:632.954(497.6)

\begin{abstract}
The aim of the study was to research the mobility of imazethapyr in three types of soil in the disturbed conditions (laboratory labels KDIL, PILKD and PILKE), whose $\mathrm{pH}$ in $\mathrm{H}_{2} \mathrm{O}$ varied from 4.55 to 7.01 using the methods of biological testing. In the study it was used PIVOT-M which contains $100 \mathrm{gl}^{-1}$ of imazethapyr as ammonium salt and is formulated as the concentrated solution (SL).

Imazethapyr was washed out through the PVC columns, with the inner diameter of 45 $\mathrm{mm}$ and $20 \mathrm{~cm}$ long $(4 \times 5 \mathrm{~cm})$. The amount of water used for eluting of the deposit amount of the herbicide suited the amount of 50, 100 and 2001 of water $/ \mathrm{m}^{2}$ and deposite amount of herbicide was $1.0 \mathrm{lha}^{-1}$. After the washout and draining of the column, the soil column was extruded and divided into the segments of $5 \mathrm{~cm}$. On the soil extract of $5 \mathrm{~cm}, 10 \mathrm{~g}$ of dry and noncontaminated soil of the same type was added to drain the extract and prepare for planting. Soil sample of $110 \mathrm{~g}$ of soil (110 $\mathrm{g}$ of the soil from the column $+10 \mathrm{~g}$ of the "pure" soil) is placed into the pot with the diameter of $5 \mathrm{~cm}$ and 8 seeds of oats were planted. Such formed pots are placed into the greenhouse in order to measure biometric indicators after 21 day (fresh mass of the shoot and root, dry mass of the shoot and root).

The mobility of imazethapyr depends on the chemical characteristics and mechanical content of the soil. In this study, placing in the regressive dependence of the soil characteristics [humus content (\%), clay (\%) and sand (\%)], as an independent variable, with the amount of water required for elution, as dependent size, they could not demonstrate dependency relationships observed through a linear regression. However, when you observe $\mathrm{pH}$ dependence of soil and water volume $(\mathrm{CV})$ required for elution of imazethapyr from the first $5 \mathrm{~cm}$ through the exponential regression of the first line, so that inhibition of oats growth, which is grown in the soil from that part of the column, was $10 \%$, and which corresponds values of NOEL, it can be drawn a conclusion that

\footnotetext{
${ }^{1}$ University of Banja Luka, Faculty of Agriculture, Student city, Bulevar vojvode Petra Bojovića 1A, 78000 Banja Luka, Bosnia and Herzegovina

2 Academy of Sciences and Arts of the Republic of Srpska, Bana Lazarevića 1, 78000 Banjaluka, Bosnia and Herzegovina

*Corresponding author: sinisa.mitric@agrofabl.org
} 
functional dependency is established $K V=98.545+3.228 \times 10^{\mathbf{s}} \times e^{-\left(\mathrm{pH}^{\mathrm{pH}} I_{0,335}\right)}$ statistically significant, with a coefficient of determination 0.987. It tells us that the mobility of imazethapyr in the soil is greater as the $\mathrm{pH}$ of the soil is greater, which means that imazethapyr is very mobile in the neutral or soils with the weak basis.

Keywords: herbicide, imazethapyr, soil, mobility, $\mathrm{pH}$ soil

\section{INTRODUCTION}

Imazethapyr [IUPAC: 5-etil-2-[(RS)-4-isopropil-4-metil-5-oxo-2-imidazolin-2-il]nikotinik acid] is a systematical herbicide from the class imidazolinone. Imezathapyr is herbicide which was greatly applied in weed control in the crops of soybean, beans, green beans, peas, lucerne and birds-foot trefoil.

The researchers have paid a great attention to studying the influence of soil $\mathrm{pH}$ on the model of the adsorption of imazethapyr, as well as the adsorption dependence on the clay type and its content and the content of the organic substances in the soil. Imazethapyr is an amphoteric compound (Stougaard et al., 1990) because of the presence of the carboxid-acid $(\mathrm{pKa}=3.9)$ as well as base hinolgroup $(\mathrm{pKa}=2.1)$. When $\mathrm{pH}$ decreases, an imazethapyr molecule will be alternatively negatively charged $(\mathrm{COO}, \mathrm{N})$ neutral $(\mathrm{COOH}, \mathrm{N})$, and then positive $(\mathrm{COOH} ; \mathrm{NH}+)$. Because of that, many authors examined dependence between $\mathrm{pH}$ of soil at one hand and adsorption of imazethapyr on colloid of the soil on the other hand. There are different opinions about that relevance. Some authors (Gennari et al., 1998; Loux et al., 1989; Gan et al., 1994; Oliveira et al., 2001) consider that $\mathrm{pH}$ of the soil has not any greater influence on the adsorption of imazethapyr. There are more authors who have the different opinion, that adsorption depends on the $\mathrm{pH}$ of the soil (Renner et al., 1998; Loux et al., 1989; Loux and Reese, 1992; Sakaliene et al., 2007; Vischetti et al., 2002; Johnson et al., 2000; Nègre et al., 2001). It is determined that there is the greater sorption of imazethapyr when the $\mathrm{pH}$ of soil decreases from $\mathrm{pH} 8$ to 3 , probably because of the influence on ionization of the different ionizing functional groups (Goetz et al., 1986;. Renner et al., 1988;. Stougaard et al., 1990). However, considering the span of $\mathrm{pH}$ of the agricultural soils, then the ionization of the acid group should have the greater influence on the sorption because the $\mathrm{pKa}$ values are very low. Loux et al. (1989, cit. Kah, Melanie, 2007) studied the sorption of imazaquin and imazethapyr in 22 different types of soil and 6 samples of sediment, whose $\mathrm{pH}$ varied from 4.2 to 8.3 , but they varied in many other aspects. The mentioned author used linear regression and established that there is a positive correlation between adsorption of imazakquin and the content of the organic carbon, but there is a negative correlation with $\mathrm{pH}$ value. Renner et al. (1998) established that the adsorption of imazaquin and imazethapyr was significantly decreased when $\mathrm{pH}$ was increased from 5.5 to 8.0. Stougard et al. (1990) also confirmed that imazaquin and imazethapyr adsorb better at lower $\mathrm{pH}$, they are less mobile and less efficient, and it results at lower 
$\mathrm{pH}$ when protonation (reduction) of the basic functional groups of the herbicide molecules appear.

Ahmad et al. (2001) established by studying the sorption of imazethapyr in 25 samples in Pakistan and Australia, that Kd value for imazethapyr moves from almost $0(0.02)$ to $6.94 \mathrm{lkg}-^{1}$. Generally, the alkali soil in Pakistan has the significantly lower Kd value than the soil in Australia. Considering sorption, on one hand, with $\mathrm{pH}$ of the soil and the content of the organic carbon in soil, on the other hand, it can be established that there is a strong correlation between the $\mathrm{pH}$ value of the soil and $\mathrm{Kd}$ and it is $\mathrm{r}=0.75$. The research showed that sorption of imazethapyr in the alkali soil of Pakistan is low, and there is considerable risk to contaminate the underground water. The same authors claim that correlation between $\mathrm{Kd}$ and the content of the organic carbon is low, only $\mathrm{r}=0.35$. Sakaliene et al. (2007) claim that there is no correlation between Kd value of the herbicide and the clay content in the soil, which means that the coefficient of the linear correlation (r) is only 0.10 .

Johnson et al. (2000) established the strong dependency of $\mathrm{Kd}$ value on soil $\mathrm{pH}$, so while measuring $\mathrm{Kd}$ in 7 different types of soil, it was determined the high negative correlation between $\mathrm{Kd}$ value and belonging $\mathrm{pH}$ of soil, while the coefficient of correlation is $\mathrm{r}=0.966(\mathrm{p}+0.000385)$. In the study of the given authors the $\mathrm{pH}$ of soil varied from 3.8 to 7.8 .

\section{MATERIAL AND METHODS}

Mobility of imatethapyr in the soil was studied by the method of the biological testing, and imazethapyr was washed out through the PVC colons with the in inner diameter of $45 \mathrm{~mm}$, which were filled with the soil sample and sand in the compromised condition. Studying the mobility of imazethapyr by the bioassay method in the colons with the compromised samples was done by the combination of methods which were applied by Woondimagegnehu Marsie and Chester (1986), Janjic et al. (1992). The characteristics of the used soil are given in the Table 1 and 2.

Table 1. General data about chemical characteristics of soil

\begin{tabular}{|c|c|c|c|c|c|}
\hline \multirow{2}{*}{$\begin{array}{c}\begin{array}{c}\text { Type of soil } \\
\text { (mark) }\end{array} \\
\end{array}$} & \multicolumn{2}{|c|}{ Reaction (pH) } & \multirow{2}{*}{$\begin{array}{c}\text { Humus } \\
(\%)\end{array}$} & \multirow{2}{*}{$\begin{array}{c}\mathrm{P}_{2} \mathrm{O}_{5} \\
(\mathrm{mg} / 100 \mathrm{~g}) \\
\end{array}$} & \multirow{2}{*}{$\begin{array}{c}\mathrm{K}_{2} \mathrm{O} \\
(\mathrm{mg} / \mathbf{1 0 0 g}) \\
\end{array}$} \\
\hline & $\mathrm{H}_{2} \mathrm{O}$ & $\mathrm{KCl}$ & & & \\
\hline PILKE & 7.01 & 6.41 & 1.8 & 6.1 & 23.1 \\
\hline KDIL & 4.55 & 3.89 & 1.4 & 4.6 & 14.0 \\
\hline PILKD & 4.81 & 3.88 & 1.8 & 3.9 & 38.4 \\
\hline
\end{tabular}


Tabele 2. Grain structure and type of soil

\begin{tabular}{ccccccc}
\hline $\begin{array}{c}\text { Type of } \\
\text { soil } \\
\text { (mark) }\end{array}$ & $\begin{array}{c}\text { Sand } \\
\mathbf{2 . 0 - 0 . 0 6} \mathbf{~ m m}\end{array}$ & $\begin{array}{c}\text { \% Grain sizes } \\
\mathbf{0 . 0 6 - 0 . 0 0 2} \mathbf{~ m m}\end{array}$ & $\begin{array}{c}\text { Clay } \\
\mathbf{0 . 0 0 2} \mathbf{~ m m}\end{array}$ & Texture & Type of soil \\
\hline \hline PILKE & 26.38 & 51.53 & 22.09 & $\begin{array}{l}\text { Silty } \\
\text { loam }\end{array}$ & Eutric cambisol \\
\hline KDIL & 36.03 & 40.96 & 23.01 & Loam & $\begin{array}{l}\text { Dystrict } \\
\text { cambisol }\end{array}$ \\
\hline PILKD & 14.79 & 67.05 & 18.16 & $\begin{array}{l}\text { Silty } \\
\text { loam }\end{array}$ & $\begin{array}{l}\text { Dystrict } \\
\text { cambisol }\end{array}$ \\
\hline
\end{tabular}

Colons were filled with the soil samples so the soil profile of $20 \mathrm{~cm}$ was formed. Soil was "jammed" to get density of ostensible soil of $1.2 \mathrm{~g} / \mathrm{cm}^{3}$. Since the colon was $20 \mathrm{~cm}$ long, and diameter was $45 \mathrm{~mm}$, the volume of the colon was $318.08 \mathrm{~cm}^{3}$ so the mass of a colon was $381.70 \mathrm{~g}$ per colon or $400 /$ colon approximately. Surface of the colon, the inner surface of the PVC tube was $15.9 \mathrm{~cm}^{2}$ (or $0.00159 \mathrm{~m}^{2}$ ), so the amount of the preparation of $1.01 \mathrm{1} / \mathrm{ha}$ matched to the amount $0.00016 \mathrm{ml}$ of preparation/colon. Preparation was applied in the amount of $0.2 \mathrm{ml}$ of the working solution on the top of colon, but $0.2 \mathrm{ml}$ of the working solution of the preparation is mixed with 1.5 quartz sand which is equally and carefully distributed on the top of the colon. Such a colon is covered with the filter paper and then the elution is done. The amount of water that was used for elution of the deposit amount of herbicide matched the amount of 50,100 and 2001 of water $/ \mathrm{m}^{2}$, which were 80,160 and $320 \mathrm{ml}$ of water per colon. The mentioned amount of distilled water was poured into the separation funnel, and then the washout process was undertaken. After the leaching-out, the colon was held to leach for 48 hours. After that the soil column was pushed out and divided into the segments of $5 \mathrm{~cm}$, starting at $0-5 \mathrm{~cm}$. The clipping of $5 \mathrm{~cm}$ was added $10 \mathrm{~g}$ of dry and non-contaminated soil of the same type to dry the clipping easily and prepare for sowing. Soil sample of $110 \mathrm{~g}$ of soil ( $100 \mathrm{~g}$ of soil from the column $+10 \mathrm{~g}$ of "pure" soil) was placed into the pot whose diameter is $5 \mathrm{~cm}$. Eight seeds of the oats were placed and those pots were placed in the greenhouse. Biometrical indicators were measured after 21 day.

\section{RESULTS}

The comparative analysis of mobility of imazethapyr in the examined soil is possible to do by comparing the regressive dependency between the amount of water that passed through the column as well as the size, and the percentage of the inhibition of the oats growth as the depending measure. The following conclusion can be drawn, the inhibition of the oats growth in segment from 0 to $5 \mathrm{~cm}$, but in the segment from 5 to 10 as well is decreasing constantly as the amount of water increases (Figure 1 and 2). Therefore, it is possible to make regressive dependency between the amount of water that passed through the soil from the upper segments of the colon $(0-5 \mathrm{~cm})$ and the fall of the inhibition of the oats growth, due to leaching out the imazethapyr on 
the depth lower than $10 \mathrm{~cm}$ (Table 2). The following question can be asked. What amount of water is necessary to wash out imazethapyr in the given soil from the upper segments of the colon to make the inhibition of the oats growth, which we grow in the soil from that part of the colon, is $10 \%$ which matches to the NOEL value (Table 3 ).

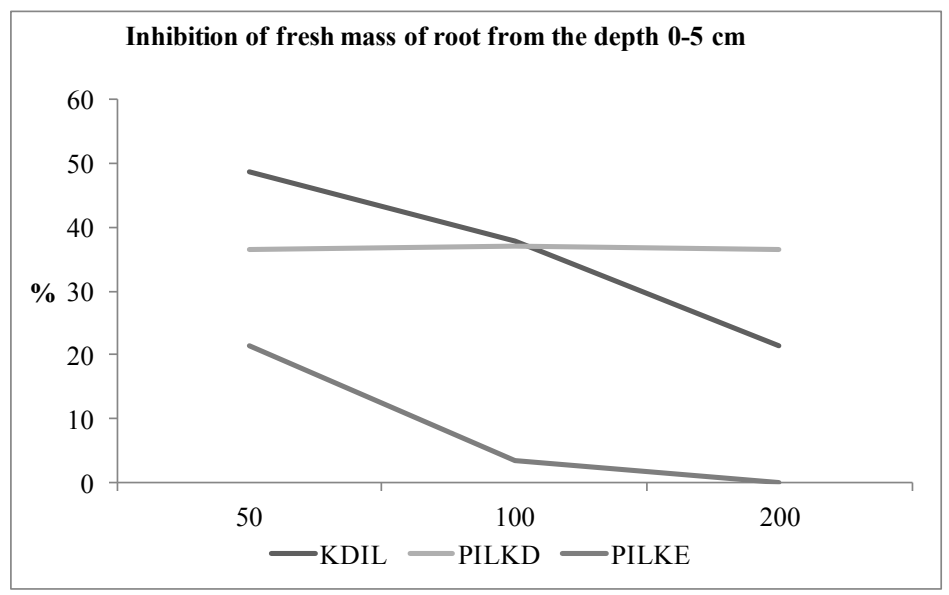

Figure 1. The comparative graph of inhibition dependency of the fresh mass of the root and the amount of the passed water on the depth of $0-5 \mathrm{~cm}$

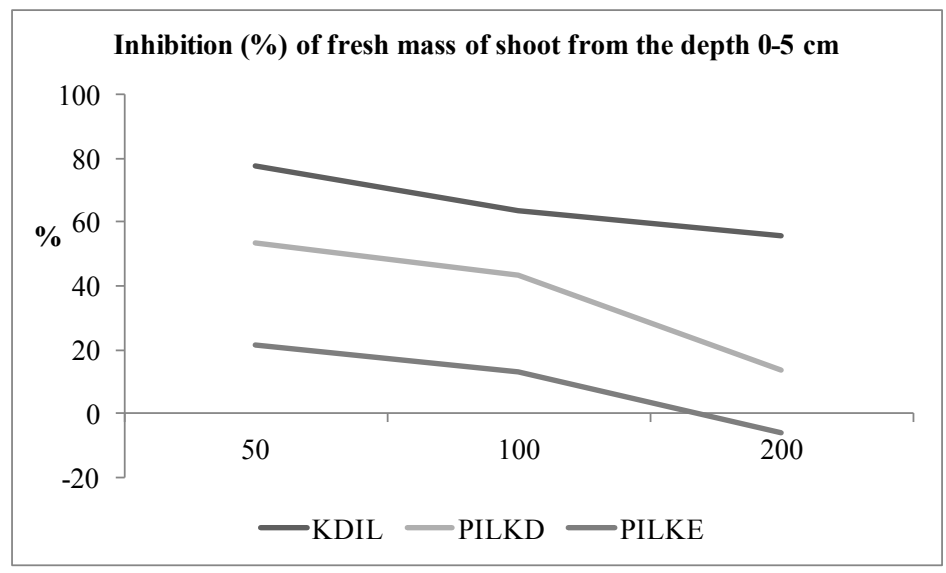

Figure 2. The comparative graph of inhibition dependency of the fresh mass of the shoot and the amount of the passed water on the depth of $0-5 \mathrm{~cm}$ 
Table 3. Regressive dependency between the growth inhibition (In) of the fresh mass of shoot and the fresh mass of the oats root in the soil at the depth of $0-5 \mathrm{~cm}$ depending on the amount of water (AW) which passes through the colon $(50$, $100,2001 / \mathrm{m}^{2}$ )

\begin{tabular}{cccc}
\hline $\begin{array}{c}\text { Biometric } \\
\text { indicators }\end{array}$ & Deep & Type of soil & $\begin{array}{c}\text { The function of the linear regression } \\
\text { with a coefficient of determination }\end{array}$ \\
\hline \hline \multirow{2}{*}{ FMS } & $0-5 \mathrm{~cm}$ & KDIL & $\operatorname{In}_{(0-5)}=81.315-0.136 \times \mathrm{AW}\left(\mathrm{r}^{2}=0.884\right)$ \\
& & PILKD & $\operatorname{In}_{(0-5)}=56.875-0.1796 \times \mathrm{AW}\left(\mathrm{r}^{2}=0.994\right)$ \\
\cline { 3 - 4 } & & PILKE & $\operatorname{In}_{(0-5)}=31.075-0.186 \times \mathrm{AW}\left(\mathrm{r}^{2}=0.935\right)$ \\
FMR & $0-5 \mathrm{~cm}$ & KDIL & $\operatorname{In}_{(0-5)}=56.875-0.180 \times \mathrm{AW}\left(\mathrm{r}^{2}=0.994\right)$ \\
\cline { 3 - 4 } & & PILKD & $\operatorname{In}_{(0-5)}=36.705-0.0002 \times \mathrm{AW}\left(\mathrm{r}^{2}=0.0018\right)$ \\
\hline & PILKE & $\operatorname{In}_{(0-5)}=23.215-0.128 \times \mathrm{AW}\left(\mathrm{r}^{2}=0.710\right)$ \\
\hline
\end{tabular}

Legend: FMS= Fresh mass of the shoot; FMR= Fresh mass of the root; In= Inhibition (\%); $\mathrm{AW}=$ The amount of water

The amount of water necessary for leaching out the deposit amount of imazethapyr from the lay on the depth of $5 \mathrm{~cm}$, actually $10 \mathrm{~cm}$, so that imazethapyr in the soil of that segment stays so long to cause the inhibition of the fresh mass of the shoot and the fresh mass of the root at $10 \%$ which is shown at the table 4 .

Table 4. The amount of water sufficient for elution of imazethapyr from the soil lay 0-5 and 5-10 $\mathrm{cm}$ on the concentration in the soil which id on the NOEL level

\begin{tabular}{|c|c|c|c|}
\hline $\begin{array}{l}\text { Biometric } \\
\text { indicators }\end{array}$ & Deep & $\begin{array}{l}\text { Type of } \\
\text { soil }\end{array}$ & $\begin{array}{c}\text { The amount of water sufficient for elution } \\
\text { of imazethapyr on the concentration in the } \\
\text { soil which id on the NOEL level }\end{array}$ \\
\hline \multirow{3}{*}{ FMS } & \multirow{3}{*}{$0-5 \mathrm{~cm}$} & KDIL & $524.4 \mathrm{l} / \mathrm{m}^{2}$ \\
\hline & & PILKD & 261.0 \\
\hline & & PILKE & 113.3 \\
\hline \multirow{3}{*}{ FMS } & \multirow{3}{*}{$\begin{array}{r}5-10 \\
\mathrm{~cm}\end{array}$} & KDIL & 414.6 \\
\hline & & PILKD & 187.0 \\
\hline & & PILKE & 187.3 \\
\hline \multirow{3}{*}{ FMR } & \multirow{3}{*}{$0-5 \mathrm{~cm}$} & KDIL & 260.4 \\
\hline & & PILKD* & - \\
\hline & & PILKE & 103.2 \\
\hline \multirow{3}{*}{ FMR } & \multirow{3}{*}{$\begin{array}{r}5-10 \\
\mathrm{~cm}\end{array}$} & KDIL* & - \\
\hline & & PILKD & 196.7 \\
\hline & & PILKE & 143.3 \\
\hline
\end{tabular}

*NOTE: Because of the small coefficient of determination, calculating the amount of water necessary for leaching out the herbicide to make the inhibition of the oats growth less than $10 \%$ would be unreliable 
According to the table 3 and regressive dependences (Table 4), we conclude that imazethapyris the most movable in the soil such as "PILKE", and the least movable in the soil of the type "KDIL".

Mobility of imezathapyr in soil also depends on the chemical characteristics and mechanical content of the soil. However, in this paper it cannot be proved the relations of dependency observed through the linear regression by putting characteristics of the soil into the regressive dependency [humus content (\%), clay (\%) and sand (\%)], as independent variable with amount of water necessary for elution as dependent variable. However, when the $\mathrm{pH}$ of soil is observed through the exponential regression of the first line and amount of water necessary for leaching out of imazethapyr from the first $5 \mathrm{~cm}$, the interesting conclusion can be drawn. Namely, such established functional

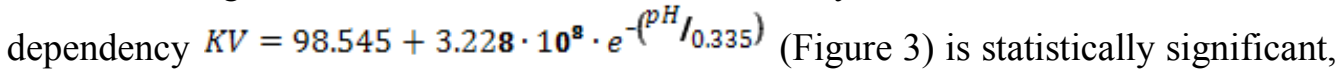
with coefficient of determination of 0.987 . It tells that mobility of imazethapyr in soil is greater if the $\mathrm{pH}$ of soil is larger, which means that imazethapyr is very mobile in neutral and weakly base soil what is proved in many quotations. In other words, in the soil of neutral and base reaction, the less amount of water is necessary to move imazethapur than it is necessary in the acid soil, which means the soil with less $\mathrm{pH}$. From the above, it can be concluded that $\mathrm{pH}$ of the soil is a dominant factor at mobility of imatethapyr.

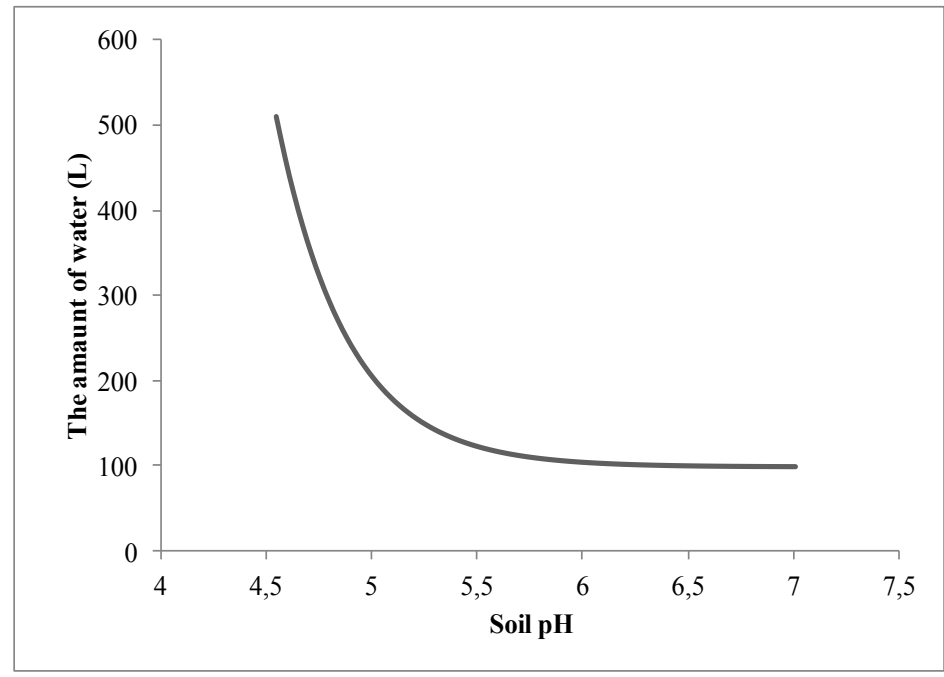

Figure 3. Regressive relation between soil $\mathrm{pH}$ and amount of water necessary for leaching out of imazethapyr 


\section{DISCUSSION}

By studying the mobility of imazethapyr and its leaching out through the colons, it can be generally said that indicators of oats growth significantly vary due to the influence of imazethapyr, and considering the amount of water used for leaching out as well as the depth of the soil layer it reached. The amount of water which is necessary to move deposit amount of imazethapyr and wash out under $5 \mathrm{~cm}$ so that it stays in segment from 0 to $5 \mathrm{~cm}$ in the amount that cause the growth inhibition of $10 \%$ is $524.41 / \mathrm{m}^{2}$ at "KDIL" soil type. At "PILKD" soil type it is $261.01 / \mathrm{m}^{2}$, while at 'PILKE' it is $113.31 \mathrm{l} / \mathrm{m}^{2}$ of water. Mobility of imazethapyr in soil also depends on chemical characteristics and mechanical content of soil. However, in this paper it cannot be proved the relations of dependency observed through the linear regression by putting characteristics of the soil into the regressive dependency [humus content (\%), clay (\%) and sand (\%)], as independent variable with amount of water necessary for elution as dependent variable. Because of that, quotations of Stougaard et al. (1990) can be confirmed where it was established that the herbicides are the least mobile in the clay loam soil with the larger content of clay and organic matter. However, when the $\mathrm{pH}$ of soil is observed through the exponential regression of the first line and amount of water necessary for leaching out of imazethapyr from the first $5 \mathrm{~cm}$, the interesting conclusion can be drawn. Namely, such established functional dependency with the coefficient of determination of 0.987 .

\section{CONCLUSIONS}

There mobility of imazethapyr in soil is greater if the $\mathrm{pH}$ of soil is larger, which means that imazethapyr is very mobile in neutral and weakly base soil what is proved in many quotations. From the above it can be concluded that $\mathrm{pH}$ is dominant factor at mobility of imazethapyr.

\section{REFERENCES}

Ahmad, R., Kookana, S. R., Alston, M. A. 2001. Sorption of ametryn and imazethapyrin twenty-five soils from Pakistanand Australia. Journal of Environmental Science and Health Part B 36(2), 143-160.

Gan, J., Weimer, M. R., Koskinen, W. C., Buhler, D. D., Wyse, D. L., Becker, R. L. 1994. Sorption and desorption of imazethapyr and 5-hydroxyimazethapyr in Minnesota soils. Weed Sci. 42, 92-97.

Gennari, M., Nègre M., Vindrola, D. 1998. Adsorption of the herbicides imazapyr, imazethapyr, and imazaquin on soils and humic acids. J. Environ. Sci. Heal. B. 33, 547-567.

Goetz, J. A., Wehtje, G., Walker, R. H., Hajek, B. 1986. Soil solution and mobylity characterization of imazaquin. Weed Sci. 34, 788-793. 
Janjić, V., Marisavljević, Dragana, Popović, Lj., Bogdanović, V. 1992. Mogućnost korišćenja ovsa (Avena sativa L.) za praćenje sadržaja i dinamike ispiranja atrazina u zemljištu. Acta herbologica, 1, 2, 221-229.

Johnson, H. D., Shaner Dale, L. D., James, D., Mackersie, A.L., Tuxhorn, G. 2000. Timedependent adsorption of imazethapyr to soil. Weed Science, 48, 769-775.

Kah, Melanie. 2007. Behaviour of ionisable pesticides in soil. PhD Thesis. University of York, Environment Department.

Loux, M. M., Liebl, A. R., Slife, W. F. 1989. Adsotption of Imazaquin on Soil, Sediments, and Selected Adsordents. Weed Science, 37, 712-718.

Loux, M. M., Reese, K. D. 1992. Effect of soil-pH on adsorption and persistence of imazaquin. Weed Sci. 40, 490-496.

Nègre, M., Schulten H.R., Gennari, M., Vindrola, D. 2001. Interaction of imidazolinone herbicides with soil humic acids. Experimental results and molecular modeling. J. Environ. Sci. Health, B36(2), 107-125.

Oliveira Jr., R. S., Koskinen, W. C., Ferreira, F. A. 2001. Sorption and leaching potential of herbicides on Brazilian soils. Weed Research, 41, 97-110.

Renner, K. A., Meggitt, W. F., Penner, D. 1988. Effect of Soil pH on Imazaquim and Imazethapir Adsorption to Soil and Phytotoxicity to Corn (Zea mays). Weed Science, 36, 78-83.

Sakaliene, Ona, Papiernik, K. S., Koskinen, C. W., Spokas, A. K. 2007. Sorption and predicted mobility of herbicides in Baltic soils. Journal of Enviromental Science and Health Part B, 42, 641-647.

Stougaard, R. N., Shea, P. J., Martin, A. R. 1990. Effect of Soil Type and pH on Adsorption, Mobility, and Efficacy of Imazaquin and Imazethapyr. Weed Science, $38,1,67-73$.

Vischetti, C., Trevisan, M., Esposito, A., Scarponi, L. 2002. Ability of three pesticide leaching models to simulate summer crops in a Mediterranean scenario. Agronomie, 22, 351-361.

Woondimagegnehu, Marsie, Chester L. Foy. 1986. Adsorption, Desorption, and Mobility of Clorsulfuron in Soils. J. Agric. Food Chem., 34, 89-92. 